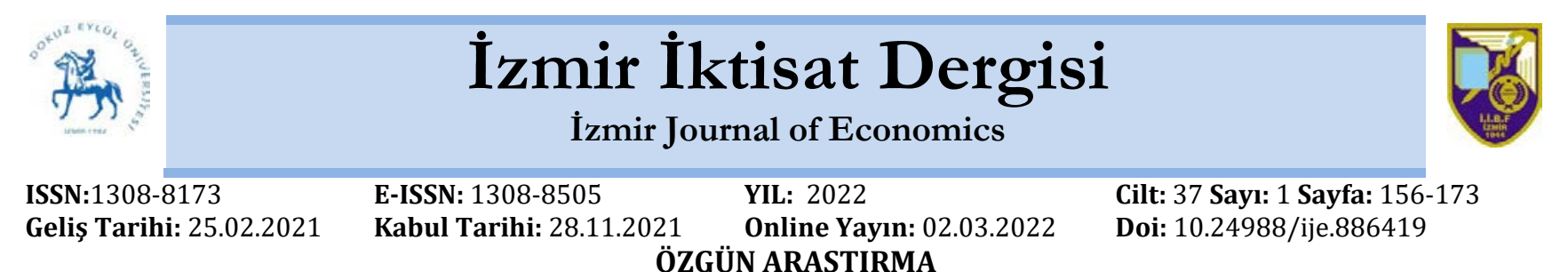

ÖZGÜN ARAŞTIRMA

\title{
Facebook'ta Verilen Reklamların, Reklam Güvenilirliği ve Bilgilendiriciliği Üzerindeki Etkisinin Araștırılması*
}

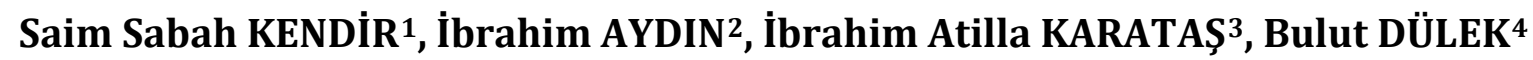

\begin{abstract}
Özet
Bu çalıșmanın bașlıca amacı Facebook'ta verilen reklamların, reklam güvenilirliği ve bilgilendiriciliği üzerindeki etkilerini farklı demografik değişkenleri de göz önünde bulundurarak araştırmaktır. Çalışmanın evreni Van'ın Erciş ilçesinde yaşayanlardır. Örneklem ise basit seçkisiz yöntem ile ulaşılan 426 kişidir. Çalışma verileri 2019'un ekim ve kasım aylarında yüz yüze anket yoluyla toplanmıştır. Çalışmanın bağımlı değişkenleri Facebook'ta verilen reklamların güvenilirliği (FRG) ve bilgilendiriciliği (FRB) iken bağımsız değişkenleri cinsiyet, eğitim durumu, yaş ve elde edilen gelirdir. Elde edilen sonuçlara göre Facebook'ta verilen reklamların bilgilendirici ve güvenilir olmadığı görülmüștür. Kadınlar ve erkekler arasında Facebook'ta verilen reklamların güvenilirliği ve bilgilendiriciliğine yönelik tutumda bir farklılı̆ga rastlanmamış, farklı gelir düzeylerine sahip olanlarda ise Facebook'ta verilen reklamların güvenilirliği ve bilgilendiriciliğine yönelik tutuma olan etkisinde farklılığın olduğu görülmüştür. Elde edilen verilerin analizi için tek örneklem t testi, tekyönlü çok değişkenli varyans analizi ve tek faktörlü varyans analizi kullanılmıştır. Çalışmada kullanılan ölçekler, bu amaca uygun bir çalışmadan alınıp, uyarlama yapılarak kullanılmıştır.
\end{abstract}

Anahtar kelimeler: Facebook Reklamları, Reklamın Güvenilirliği, Reklamın Bilgilendiriciliği

Jel Kodu: M30, M31, M37

\section{Investigation of the Effects of Advertising on Facebook on Reliability and Informativeness of Advertising \\ Abstract}

The purpose of this study is to investigate the effects of Facebook ads on the attitudes towards the informativeness of the advertisement and the reliability of the advertisement by taking into account different demographic variables. The population of the study consists of people who living in Ercis district of Van and its sample consists of 426 people selected by simple random method. Study data were collected through face-to-face surveys in October and November 2019. The dependent variables are the informativeness of the advertisement and the reliability of the advertisement while the independent variables of the study are gender, age, education level and income. According to the results, it has been observed that the advertisements on Facebook are not informative and reliable.There was no difference between men and women in attitude towards towards the informativeness of the advertisement and the reliability of the advertisement, and in those with different income levels, there was a difference in the attitude towards towards the informativeness of the advertisement and the reliability of the advertisement. One sample t test, one-way multivariate analysis of variance and one-factor analysis of variance were used for the analysis of the data obtained. The scales used for the study were taken from a study suitable for the purpose of the study and used after adaptation.

Keywords: Facebook Ads, Reliability of the Advertisement, Informativeness of the Advertisement

Jel Codes: M30, M31, M37

ATIF ÖNERİsí (APA): Kendir, S. S., Aydın, İ., Karataş İ. A., Dülek, B. (2022). Facebook'ta Verilen Reklamların, Reklam Güvenilirliği ve Bilgilendiriciliği Üzerindeki Etkisinin Araştırılması. İzmir Íktisat Dergisi. 37(1). 156-173. Doi: $10.24988 /$ ije.886419

* Bu makale, Van Yüzüncü Yıl Üniversitesi Sosyal Bilimler Enstitüsü İşletme Anabilim Dalı'nda Saim Sabah Kendir tarafından "Facebook Reklamlarının Reklama Yönelik Tutum, Reklamdaki Bilgilere Yönelik Tutum ve Satın Alma Niyeti Üzerindeki Etkisinin Araştırılması” ismiyle tamamlanarak 05.01.2021 tarihinde savunulan yüksek lisans tezinden türetilmiștir.

${ }_{1}^{1}$ Bilim Uzmanı, Erciş Nüfus Müdürlüğü, Erciş/Van, EMAIL: saimkendir@gmail.com, ORCID: 0000-0001-7809-3305

2 Dr. Öğr. Üyesi, Van Yüzüncü Yıl Üniversitesi, Erciş İşletme Fakültesi, Erciş/VAN, EMAIL: aydnibrhm@hotmail.com, ORCID: 0000-0002-0720-364X

3 Dr. Öğr. Üyesi, Muş Alparslan Üniversitesi, İktisadi ve İdari Bilimler Fakültesi, Merkez/MUŞ, EMAIL: ibrahimatillakaratas@gmail.com ORCID: 0000-0003-4483-0244

4 Dr. Öğr. Üyesi, Van Yüzüncü Yıl Üniversitesi, İktisadi ve İdari Bilimler Fakültesi, Merkez/VAN, EMAIL: bulutdulek@yyu.edu.tr, ORCID: 0000-0002-3474-7220 


\section{GíRiş}

İnternete erişim olanağı sağlayan araçların yaygınlaşması ve hemen her yerde kullanılması, yeni dijital ortamların meydana çıkması ve bunun yanında internetin de daha etkin şekilde kullanılması radyo, televizyon ve gazete gibi kitlelere hitap eden iletişim araçlarının geleneksel medya olarak görülmesine neden olmuştur. Önceleri yeni medya içerisinde anılan televizyon, şimdilerde geleneksel medya içinde yer almaktadır (Aydın, 2020: 110). Birkaç on yıl önce, televizyon en heyecan verici teknolojik gelişmeydi ve toplumu benzeri görülmemiş bir şekilde dönüştürdü. Bugün internet üzerinden benzer bir dönüşüm ve sosyal medyanın yükseliși görülmektedir. Değișen dünyada teknoloji var olduğu her yerde geçirdiği hızlı değişimle toplumu etkilemektedir (Sheth, 2018: 3). Tüketiciler internet vasıtasıyla hemen her yerdeki firmalar ve insanlarla, günün her saatinde iletişim kurabilmekte, çeşitli şekillerde bilgiyi kontrol edebilmekte ve içerik oluşturabilmektedir (Aydın, 2020: 116). Günümüzün iletişim araçları içerisinde yer alan internetin en önemli uygulamaları arasında hiç şüphesiz sosyal medya yer almaktadır. Günlük hayatımızda internetin gittikçe daha fazla yer alması ile birlikte bu durum sosyal medyanın sıklıkla kullanılmasına yol açmakta ve sosyal medya; bilgi edinme, eğlence, arama yapma gibi birçok konuda da insanların ihtiyacını karşılamaktadır (Hazar, 2011: 153). Her zaman ve her yerde mobil aygıtlar vasıtasıyla sosyal ağlara ulaşabilme firsatının olması, sosyal medyayı daha da vazgeçilmez kılmıștır (Aslan ve Yaşar, 2020: 469). Geçmişten beri sıklıkla kullanılan ağızdan ağıza iletişim insanların sosyal ağlarda çokça vakit geçirmeleri ile birlikte bu ortamlarda da oldukça yoğun bir şekilde yapılmaktadır. Ayrıca yeni bir ürünü ya da markayı kullanmayı düşünen tüketiciler de bu ürün veya markayla ilgili diğer tüketicilerin deneyimlerinden faydalanmak ister ve sosyal ağlar vasıtasıyla başka insanlardan bilgi elde edebilirler (Dülek ve Aydın, 2020: 272). Bu etkileşimler, tüketicilere fırsatlar sunduğu gibi firmalara da firsatlar sunmaktadır (Hajli, 2014: 399). Sosyal medyada firmalar, hedef kitleleri ile iletişimi koparmamak, tüketicilerin istek, ihtiyaç ve fikirlerini öğrenmek, hedef kitleleri ile hiçbir aracı olmadan ve kişiselleștirilmiş etkileşimde bulunma fırsatına sahiptirler (Constantinides ve Fountain, 2008: 233). Sosyal medya platformlarında işletmeler, insanların marka ve ürünlerini nasıl algıladığı hakkında sağlam bilgiler edinebilirler (Kim ve Ko, 2010: 166; Evans ve McKee, 2010: 114). $\mathrm{Bu}$ da pazarlama bilgi sistemi için harika bir durumdur (Evans ve McKee, 2010: 114). Sosyal medya platformlarının tutundurma ve bütünleşik pazarlama iletişimi bakımından oldukça önemli olduğunun anlaşılmasıyla Facebook, Instagram, LinkedIn, Twitter gibi platformlar firmalar açısından vazgeçilmez reklam mecraları hâlini almıştır (Kazançoğlu vd., 2012: 177). Facebook'ta verilen reklamlar, tüketiciler için bu reklamlarla etkileşime girme, paylaşma, beğenme gibi imkânlar verip aynı reklamların kimler tarafından beğenildiği ya da paylaşıldığının görüntülenmesine olanak tanır (Dehghani ve Tumer, 2015: 598).

Bir reklamın etkinliği, bilgilendirici olmasına bağlı olabilir (Goodrich vd., 2015: 39). Ayrıca, yararlı bilgiler içeren reklamlar daha iyi karşılanır (Edwards vd., 2002: 92). Bilgilendirici reklamlar, reklama yönelik olumlu tutumlarla beraber markaya yönelik de olumlu tutumlara neden olmaktadır (Janssens ve De Pelsmacker, 2005: 387). Facebook sayfalarında yer alan bilgilendirici uygulamaların marka değeri boyutları (marka farkındalığı ile çağrışımları, algılanan kalite ve marka sadakati) üzerinde etkisi bulunmaktadır (Gümüş vd., 2013: 87).

Reklamın başlıca amaçlarından biri de bilgilendirmedir (Kotler ve Armstrong, 2018: 453). Bu amacın yerine getirilebilmesi için tüketicilerin bir bilgi kaynağı olarak reklamlara güvenmesi oldukça önemlidir. Zira güven; ikna etmenin öncülü, bilginin kabul edilmesi ve tüketici satıcı ilişkilerinin temel yapı taşıdır (Soh vd., 2007: 455-456).

Reklamlara yönelik tutumlarda, farklı demografik gruplar arasında tutarlılık olabileceği gibi gruplar arasında farklılıklar da olabilir. İletişimin stratejik olarak belli bir grup hedeflenerek yapılmasının önemi göz önüne alındığında, reklam yoluyla ortaya çıkan tutumların demografik gruplar arasında olabilecek farklıklarının dikkate alınıp, incelenmesi oldukça makul görünmektedir (Shavit vd., 1998: 
7). Dolayısıyla reklamların bilgilendiriciliğinin ve güvenilirliğinin demografik farklılıkların da göz önüne alınarak anlaşılması oldukça önemlidir.

İnsanların sosyal medyayı özellikle son on beş yıldır oldukça yoğun bir şekilde kullanmasıyla beraber bu durum firmaların tüketicilere zaman ve mekân sınırı olmadan ulaşabilmesinin önünü açmıştır. Günümüzde sosyal medyada en fazla kullanıcıya sahip uygulama olan Facebook; firmaların, pazarlama iletişimi faaliyetlerini gerçekleştirebilmeleri açısından oldukça önemli bir platformdur. Facebook vasıtasıyla her gün milyonlarca mesaj dünyanın her yerine ulaşabilirken, bunlar içinde firmaların reklamları da yer almakta ve bu reklamların tüketicileri bilgilendirmesi ayrıca güvenilir olması beklenmektedir.

Reklamlar, insanların özelliklerine göre farklı tepkilere neden olabilmektedir. Yaş, cinsiyet, gelir, eğitim durumu, medeni hal, sosyo-kültürel yapı gibi insanların reklamlara verdiği tepkiyi değiştirebilecek çok sayıda özellik vardır. Pazarlama literatürüne bakıldığında tüketici davranışları incelenirken bahsi geçen özelliklerin ele alındığı çok sayıda çalışma vardır. İş dünyasında ise hedef kitlenin doğru seçilebilmesi ve etkili reklamlar yapılabilmesi için farklı özellikteki tüketicilerin reklamlara verdiği tepkilerin anlaşılması oldukça önemlidir.

Bu çalışmanın amacı; son verilere göre 2 milyar 700 milyon kullanıcı sayısını aşan ve bu sayıyla en çok kullanıcıya sahip sosyal ağ olan Facebook'ta (Statista, 2020) verilen reklamların, reklamın bilgilendiriciliğine ve güvenilirliğine yönelik tüketici tutumlarına olan etkilerini araștırmaktır. Bu etkiler araştırılırken yaş, cinsiyet, eğitim durumu ve aylık gelir değişkenleri göz önünde bulundurulmuştur.

Literatür incelemesinde Facebook'ta verilen reklamların, reklamın güvenilirliğine olan etkisinin araştırıldığı herhangi bir çalıșmaya rastlanılmamıștır. Facebook'ta verilen reklamların, reklamın bilgilendiriciliğine olan etkisinde ise yaş, gelir ve eğitim durumu değişkenlerinin araştırıldığı herhangi bir çalıșma görülmemiştir. Çalışmanın bu özgün yönlerinin ortaya çıkaracağı sonuçların literatüre katkı sağlayacağı beklenmektedir. İş dünyası için büyük kitlelere ulaşma firsatı veren Facebook gibi bir platformdaki reklamlardan tüketicilerin nasıl etkilendiğinin anlaşılmasının iş dünyası açısından da önemli olacağı düşünülmektedir. Ayrıca reklamın güvenilir olmasının önemi (Soh vd., 2007: 455-456), bilgilendirici olmasının önemi (Goodrich vd., 2015: 39; Edwards vd., 2002: 92; Janssens ve De Pelsmacker, 2005: 387; Gümüş vd., 2013: 87) ve reklamlara yönelik tutumlarda farklı demografik gruplar arasında farklılıkların olup olmamasının incelenmesinin önemi (Shavit vd., 1998: 7) göz önüne alındığında çalışmadan elde edilecek sonuçların hem literatür hem de iş dünyası açısından daha da önemli olacağı șeklinde değerlendirilmektedir.

\section{LITERATÜR VE HIPOTEZLER}

Literatür incelendiğinde Facebook'ta verilen reklamların tüketici davranıșları üzerinde neden olduğu etkiler ile ilgili çok az sayıda çalışmanın yapılması nedeniyle Facebook'ta verilen reklamların; sosyal medya, internet ve sosyal medyada gerçekleştirilen pazarlama iletişiminin de içinde yer aldığı değerlendirildiğinden, buralarda yer alan reklamların tüketici davranışları üzerinde neden olduğu etkilerin araştırıldığı çalışmalara da bakılmıştır. Sosyal medya, internet ve sosyal medyada gerçekleştirilen pazarlama iletişiminin tüketici davranışları üzerinde neden olduğu etkileri araştıran çalışmaların incelenmesinde bazı çalışmalarda tüketicilerin sosyal medya reklamlarına kayıtsız kaldıkları ya da olumsuz yönde etkilendikleri belirtilirken; başka çalışmalarda ise olumlu yönde etkilendikleri sonucuna ulaşılmıştır. Elde edilen bu bilgilerin hipotez kurulmasına yardımcı olacağı düşünülmektedir.

Barreto (2013: 134-135), göz takip teknolojisi kullanarak yaptığı deney ve daha sonra gerçekleştirdiği anket uygulaması sonucunda, Facebook'ta verilen banner reklamların bilgilendirici olmadığını, kadınlar ile erkekler arasında Facebook'ta verilen reklamlara yönelik tutumlarda 
herhangi bir farklılığa rastlanmadığını belirtirken; Özdalili ve arkadaşları (2018: 87), kadın Facebook kullanıcılarının reklamlardan daha fazla etkilendiğini ve bunları paylaşmaya istekli olduğunu, ancak erkek kullanıcıların Facebook reklamlarını kadınlar kadar paylaşma veya okuma eğiliminde olmadığını tespit etmişlerdir. Chandra ve arkadaşları (2012: 4), tarafından yapılan çalışmada da sosyal medyada verilen reklamlara karşı olumsuz tutumların olduğu görülmüştür. Aynı şekilde Bannister ve arkadaşları (2013: 16), Facebook'ta verilen reklamlara yönelik duyguların ya olumsuz olduğunu ya da katılımcıların bu reklamlara karşı kayıtsız kaldığı sonucuna varmış fakat Facebook reklamlarına yönelik kadınların erkeklere göre daha olumlu görüşlerinin olduğu sonucuna ulaşmışlardır. Torlak ve Ufuk (2014: 92) ise Facebook reklamlarına olan ilgi seviyesinin oldukça düşük bir seviyede olduğunu tespit etmişlerdir.

Duffett (2017: 15)'in çalışmasında, Facebook'taki ticari iletişimin tüketici davranışları üzerinde oluşturduğu etkileri anlamak için yaptığı çalışmada, bu iletişimin bilgilendirici olduğu, iletişime yönelik tutumu olumlu etkilediği sonucuna varılırken, kadınların erkeklere göre Facebook'taki ticari iletişimden bilgilendirici olma bakımından daha olumlu etkilendikleri özellikle yaşı büyük olanların küçük olanlara göre daha olumlu etkilendikleri ortaya çıkmış; Mir (2012: 279-280)'in çalışmasında, sosyal medyada verilen reklamlara karşı olumlu yönde tutumların olduğu ve bu reklamların bilgilendirici olduğu sonucuna ulaşılmıştır. Akar ve Topçu (2011: 52-60), yaptıkları çalışmada sosyal medya pazarlamasına yönelik tutumların genel olarak olumlu olduğunu erkekler ve kadınlar arasında herhangi bir farklılığa rastlamadıklarını belirtmişler fakat sosyal medya pazarlamasına yönelik yüksek gelire sahip olanların düşük gelire sahip olanlara göre daha olumlu tutum içinde oldukları sonucuna ulaşmışlardır. Lewis (2010) ise lise öğrencileri ile gerçekleştirdiği çalışmada kızların erkeklere göre sosyal medyaya daha pozitif yaklaştıklarını; 3 ve 4 . sınıf öğrencilerinin, 1 ve 2. sınıf öğrencilerine göre sosyal medyaya daha olumlu baktıklarını tespit etmişlerdir.

Yukarıda verilen çalışmalardaki bilgiler ışı̆̆ında aşağıdaki hipotezler kurulmuştur.

H1. Facebook reklamlarının, reklamın bilgilendiriciliği üzerinde anlamlı etkisi vardır.

H2. Facebook reklamlarının, reklamın bilgilendiriciliği üzerindeki etkisi erkekler ve kadınlar arasında anlamlı olarak farklılaşmaktadır.

H3. Facebook reklamlarının, reklamın bilgilendiriciliği üzerindeki etkisi yüksek ve düşük gelirliler arasında anlamlı olarak farklılaşmaktadır.

H4. Facebook reklamlarının, reklamın bilgilendiriciliği üzerindeki etkisi farklı yaş grupları arasında anlamlı olarak farklılaşmaktadır.

H5. Facebook reklamlarının, reklamın bilgilendiriciliği üzerindeki etkisi farklı eğitim düzeyleri arasında anlamlı olarak farklılaşmaktadır.

H6. Facebook reklamlarının, reklamın güvenilirliği üzerinde anlamlı etkisi vardır.

H7. Facebook reklamlarının, reklamın güvenilirliği üzerindeki etkisi erkekler ve kadınlar arasında anlamlı olarak farklılaşmaktadır.

H8. Facebook reklamlarının, reklamın güvenilirliği üzerindeki etkisi yüksek ve düşük gelirliler arasında anlamlı olarak farklılaşmaktadır.

H9. Facebook reklamlarının, reklamın güvenilirliği üzerindeki etkisi farklı yaş grupları arasında anlamlı olarak farklılaşmaktadır.

H10. Facebook reklamlarının, reklamın güvenilirliği üzerindeki etkisi farklı eğitim düzeyleri arasında anlamlı olarak farklılaşmaktadır. 


\section{METADOLOJÍ}

\subsection{Evren, Örneklem, Veri Toplama Süreci ve Veri Toplama Araçları}

Bu çalışmanın evreni 2019 yılının ekim ve kasım aylarında Van'ın Erciş ilçesinde yaşayan 175.108 kişiden oluşmaktadır (Nufusu.com, 2020). Araştırmanın örneklemi ise; ilk etapta evren içerisinden basit tesadüfi örnekleme yöntemiyle seçilen 507 kişiden oluşmuştur. Örneklemin evreni temsil derecesinin geçerliliği için Krejcie ve Morgan'ın gerekli örneklem büyüklüğünü belirlemede kullandıkları formülden yararlanılmıștır (1970: 608). Yapılan hesaplamada \%95'lik güven düzeyi için 175.108 kişilik evrende 384 kişilik örneklemin yeterli olacağı belirlenmiştir. Facebook reklamları ile karşılaşmadığını ifade eden 43 kişi ile anketin geri kalanına devam edilmemiş ve bu anketler çalışmadan çıkarılmıştır. Facebook reklamları ile karşılaşan kişi sayısı 464 olup bu kişiler, katılımcıların \%91,5'ini oluşturmaktadır. Elde edilen anketler incelendikten sonra anket koşullarına uymayan 36 anket ve uç değer kapsamında yer alan 2 anket çalışmadan çıkarılmış, veri analizine uygun olan 426 anket ile sonraki analizlere devam edilmiştir. Sonuç olarak örneklem, Facebook reklamları ile karşılașmış olan 426 kişiden oluşmaktadır. Çalışmaya katılanların 116'sı 18-23, 96'sı 24-29, 120'si 30-35, 52'si 36-41, 28'i 42-47, 10’u 48-53 yaş aralığında ve 4'ü 54'ten daha büyük yaştadır. Katılımcıların 118'i kadın, 308'si ise erkektir. 68 katılımcı ilköğretim, 160 katılımcı lise, 184 katılımcı üniversite ve 14 katılımcı lisansüstü eğitim mezunudur. Katılımcılardan 190'nı 0-2000 TL, 104'ü 2001-3000 TL, 60‘3001-4000 TL, 42'si 4001-5000 TL aralığında ve 30’u ise 5000 TL üzeri bir gelire sahiptir.

Anket çalışması, hem reklamdaki bilgiye yönelik hem de reklamın güvenilirliğine yönelik tutum için Chi'nin (2011: 51) çalışmasındaki ölçeklerden faydalanılarak gerçekleştirilmiştir.

\subsection{Geçerlilik ve Güvenilirlik Analizleri}

Çalışmada kullanılan ölçek için Cronbachs Alpha değeri ,881 bulunmuştur. Bu değere göre ölçek yüksek güvenilirliğe sahiptir. İki alt ölçek için güvenilirlik değerleri tablo 1'de verilmiştir.

Faktör içerisinde yer alan maddeler aşağıldaki gibidir:

Facebook reklamları güvenilirdir (FRG-1).

Facebook reklamları inandırıcıdır (FRG-2).

Facebook reklamları doğrudur (FRG-3).

Facebook reklamları gerçektir (FRG-4).

Facebook reklamları dürüsttür (FRG-5).

Facebook reklamları uygun bir ürün bilgisi kaynağıdır (FRB-1).

Facebook reklamları, piyasadaki en yeni ürünler hakkında beni bilgilendirir (FRB-2).

Facebook reklamları, güncel ürün bilgileri için iyi bir kaynaktır (FRB-3).

Facebook reklamları bana özel ürünlerin fiyat bilgilerini almama yardımcı olur (FRB-4).

Keşfedici faktör ve güvenilirlik analizi sonuçları Tablo 1'de verilmiştir. 
Tablo 1. Faktör ve Güvenilirlik Analizi Sonuçları

\begin{tabular}{|c|c|c|c|c|}
\hline Faktör İsmi & Faktör İfadeleri & Faktör Yükü & $\begin{array}{c}\text { Açıklanan Varyans } \\
\%\end{array}$ & Cronbachs Alpha \\
\hline \multirow{5}{*}{ FRG } & FRG-4 & ,888 & \multirow{5}{*}{52,813} & \multirow{5}{*}{,915 } \\
\hline & FRG-3 & 874 & & \\
\hline & FRG-1 & ,872 & & \\
\hline & FRG-5 & ,863 & & \\
\hline & FRG-2 & ,812 & & \\
\hline \multirow{4}{*}{ FRB } & FRB-3 & 905 & \multirow{4}{*}{19,345} & \multirow{4}{*}{840} \\
\hline & FRB-4 & 850 & & \\
\hline & FRB-2 & 840 & & \\
\hline & FRB-1 & 645 & & \\
\hline \multicolumn{2}{|c|}{ Açıklanan Toplam Varyans \% } & \multicolumn{2}{|c|}{72,158} & \\
\hline \multicolumn{3}{|c|}{ Kaiser-Meyer-Olkin (KMO) Örnekleme Yeterliliği Ölçütü } & \multicolumn{2}{|c|}{,854 } \\
\hline \multirow{3}{*}{\multicolumn{3}{|c|}{ Bartlett's Küresellik Testi }} & Yaklaşık Ki-Kare & 2336,565 \\
\hline & & & $\mathrm{df}$ & 36 \\
\hline & & & $\mathrm{p}$ & ,000 \\
\hline
\end{tabular}

Faktör analizi için örneklem büyüklüğünün yeterli düzeyde olup olmadığını anlamak için KaiserMeyer-Olkin (KMO) değeri ve Barlett Küresellik Testi incelenmiştir. KMO değerinin ,854 ve Barlett Küresellik Testi'nin anlamlı sonuç verdiği $(\chi 2$ (36) =2336,565; $p<, 001)$ görülmüştür. Buna göre veri setinin Keşfedici Faktör Analizine uygun olduğu anlaşılmıştır.

Temel bileşenler analizi ve eğik döndürme yöntemlerinden biri olan Direct Oblimin yöntemi kullanılarak ölçeğin faktör yapısı belirlenmiştir. Bu işlemler neticesinde toplam varyansın \%72,158'ini açıklayan 2 faktörlü bir yapıya ulaşılmıştır. Alt faktörlerin her birinin toplam varyansın \%5’inden fazlasını açıkladı̆̆ı belirlenmiştir. Buna göre ölçeğin yapı geçerliliği sağlanmıştır.

\subsection{Verilerin Analizi}

Cinsiyet bağımsız değişkenin, reklamın bilgilendiriciliği ve güvenilirliğine yönelik tutum bağımlı değişkenlerinde meydana getirdiği farklılıkların belirlenebilmesi amacıyla tek yönlü MANOVA analizi kullanılmak istenmektedir. MANOVA testinin kullanılabilmesi birçok ön şarta bağlıdır (Akbulut, 2010: 156; Alpar, 2011: 204; Tabachnick ve Fidell, 2015: 279; Stevens, 2009: 217). Uygulamalı çalışmaların çoğunda ön şartların bazıları ya da tamamı ihlal edilebilmektedir. Ancak güvenilir sonuçlara ulaşılabilmesi, ön şartlara bağlıdır (Sharma, 1996: 374). Bu şartların yerine getirilip getirilmediğini öğrenebilmek için aşağıda verilen işlemler gerçekleştirilmiştir.

MANOVA analizinin yapılabilmesi, her grupta en az bağımlı değişken sayısı kadar katılımcı olmasına bağlıdır. Bu şartın yerine getirildiği anlaşılmıştır. 
Tek değişkenli normallik şartının sağlanabilirliğinin anlaşılması amacıyla bağımlı değişkenlerin çarpıklık-basıklık değerlerine bakılmış ve bu değerlerin -1 ile 1 arasında olduğu görülmüştür. Buna göre tek değişkenli normallik şartı sağlanmıştır.

Çok değişkenli normal dağılım şartının yerine getirilip getirilmediğinin anlaşılması için Mahalanobis uzaklık değerleri incelenmiştir. Mahalanobis uzaklıkları baz alınıp çok değişkenli uç değer analizi $(p<0,001)$ yapılmış ve Mahalanobis uzaklığı değeri $x^{2}(2)=13,82$ 'nin üzerinde olan 2 veri uç değer olarak belirlenmiş ve veri setinden çıkarılmıştır.

Saçılma diyagram matrisleri incelenmiş, saçılım grafiklerinin elips şeklinde olduğu görülmüştür. Buna göre çok değişkenli doğrusallık şartının sağlandığı belirlenmiştir.

Hata varyanslarının homojenliği şartı için, bağımlı değişkenlerin her biri için hata varyanslarının homojenliği Levene F testiyle test edilmiş ve elde edilen değerler aşağıda tablo 2'de verilmiştir.

Tablo 2: Hata Varyanslarının Homojenliğine İlişkin Levene F Testi Sonuçları

\begin{tabular}{|c|c|c|c|c|}
\hline Değișkenler & F & Sd1 & Sd2 & P \\
\hline FRG &, 012 & 1 & 422 &, 914 \\
FRB &, 106 & 1 & 422 &, 745 \\
\hline
\end{tabular}

Tablo 2'de görüldüğü gibi iki değişkende de varyans eşteşliği şartı sağlanmıştır. Zira iki değişken için anlamlı olmayan bir sonuca ulaşılmıştır.

Tablo 3: Varyans - Kovaryans Matrisinin Homojenliği Testi

\begin{tabular}{|c|c|c|c|c|c|}
\hline & Box' s M & Sd1 & Sd2 & F & P \\
\hline Değer & 4,435 & 3 & 911775,6 & 1,468 &, 221 \\
\hline
\end{tabular}

Tablo 3'te görüldüğü üzere Box's M testi sonucunda anlamlılık değerinin 0,221 bulunması varyanskovaryans matrislerinin homojenliği şartının sağlandığı anlamına gelmektedir.

Manova testinin yapılabilmesi için çoklu doğrusal bağıntı ve tekillik koşulunun sağlanması gerekmektedir. Bu koșulun sağlanması bağımlı değişkenler arasındaki korelasyon değerinin orta düzeyde olmasına bağlıdır. Bağımlı değişkenler için Pearson korelasyon testi yapılmış 0,395 korelasyon değerine ulaşılmıştır. Buna göre bağımlı değişkenler arasında tekillik sorunu yoktur.

Cinsiyet değişkeni için MANOVA testinin uygulanmasında herhangi bir engel bulunmamıştır.

Yaş, gelir ve eğitim düzeyi bağımsız değişkenlerinin, bağımlı değişkenler olan reklamın bilgilendiriciliği ve güvenilirliğine yönelik tutum ile ilgili meydana getirdiği farklılıkların belirlenebilmesi amacıyla tek yönlü MANOVA analizi kullanılmak istenmiştir. Fakat bu değişkenlerin hiçbirinde varyans-kovaryans matrislerinin homojenliği şartının tutturulamadığı görülmüştür. Varyansların eşteşliği şartına bakıldığında yaş değişkeninde FRG için sağlanmış fakat FRB için sağlanamadığı görülmüștür. Gelir değişkeninde ise FRG için sağlanamamış fakat FRB için sağlanmıştır. Eğitim düzeyi değişkeninde ise FRG için sağlanamamış fakat FRB için sağlanmıştır. Dolayısıyla yaş, gelir ve eğitim düzeyi bağımsız değişkenleri için tek yönlü ANOVA testi gerçekleştirilmiştir.

Sonuç olarak değişkenlerin özelliklerine göre uygun olan; tek örneklem t testi, tek yönlü MANOVA ve tek faktörlü ANOVA analizleri kullanılmıştır.

\section{BULGULAR}

Facebook reklamlarının, tüm katılımcılarda reklamın bilgilendiriciliği ve güvenilirliğine yönelik tutum üzerine olan etkisinin anlaşılabilmesi amacıyla tek örneklem için t-testi uygulanmış, veriler 0,05 anlamlılık düzeyinde analiz edilmiştir. Elde edilen bulgular tablo 4 ve tablo 5 'te verilmiştir. 
Tablo 4: Facebook Reklamlarının Reklamın Güvenilirliğine Yönelik Tutum Ölçeğine İlişkin Tek Örneklem t Testi

\begin{tabular}{|l|c|c|c|c|}
\hline \multirow{2}{*}{ Bağımlı değiş̧ken } & \multicolumn{4}{|c|}{ Test Value: $\mathbf{3}$} \\
\cline { 2 - 5 } & $\overline{\mathbf{x}}$ & $\mathbf{S d}$ & $\mathbf{t}$ & P \\
\hline \multirow{2}{*}{ FRG } & 2,19 & 425 & $-18,44$ &, 000 \\
\hline
\end{tabular}

Yukarıdaki tabloda görüleceği gibi Facebook reklamlarının, reklamın güvenilirliğine yönelik tutumlarda olumlu veya olumsuz yönde etkilenme düzeylerini anlamlı bir farklılaşmaya neden olacak şekilde etkilediği sonucuna ulașllmıștır $(t 425=-18,44, p<, 05)$. Ortalama değerine $(\bar{x}=2,19)$ bakıldığında bu farklılaşmanın olumsuz yönde olduğu anlaşılmıştır.

Tablo 5: Facebook Reklamlarının Reklamın Bilgilendiriciliğine Yönelik Tutum Ölçeğine İlişkin Tek Örneklem t Testi

\begin{tabular}{|l|c|c|c|c|}
\hline \multirow{2}{*}{ Bağımlı değişken } & \multicolumn{4}{|c|}{ Test Value: $\mathbf{3}$} \\
\cline { 2 - 5 } & $\overline{\mathbf{x}}$ & $\mathbf{S d}$ & $\mathbf{t}$ & $\mathbf{P}$ \\
\hline FRB & 2,53 & 425 & $-10,17$ &, 000 \\
\hline
\end{tabular}

Tablo 5'te görüldüğü gibi Facebook reklamlarının, reklamın bilgilendiriciliğine yönelik tutumlarda olumlu veya olumsuz yönde etkilenme düzeylerinde anlamlı bir farklılaşmaya neden olduğu görülmüştür (t425=-10,17, p<,05). Ortalama değerine $(\bar{x}=2,53)$ bakıldığında bu farklılaşmanın olumsuz yönde olduğu anlaşılmıştır.

Facebook reklamlarının erkekler ve kadınlar arasında, reklamın güvenilirliğine ve bilgilendiriciliğine yönelik tutumda bir farklılığın olup olmadığının anlaşılması amacıyla gerçekleştirilen MANOVA testi ile ilgili bilgiler tablo 6'da verilmiştir.

Tablo 6: Cinsiyet Değişkenine Göre Reklamın Güvenilirliği ve Bilgilendiriciliğine Yönelik Tutum Ölçekleri Ortalama Puanlarına İlişkin MANOVA Testi Sonuçları

\begin{tabular}{|c|c|c|c|c|c|c|c|}
\hline $\begin{array}{l}\text { Varyansın } \\
\text { kaynağı }\end{array}$ & $\begin{array}{l}\text { Bağımlı } \\
\text { değişken }\end{array}$ & KT & Sd & KO & $\mathbf{F}$ & $\mathbf{p}$ & $\eta^{2}$ \\
\hline Cinsiyet & $\begin{array}{l}\text { FRG } \\
\text { FRB }\end{array}$ & $\begin{array}{l}, 000 \\
1,07\end{array}$ & $\begin{array}{l}1 \\
1\end{array}$ & $\begin{array}{l}, 000 \\
1,07\end{array}$ & $\begin{array}{l}, 001 \\
1,69\end{array}$ & $\begin{array}{l}97 \\
\text {, } 28\end{array}$ & $\begin{array}{l}000 \\
, 003\end{array}$ \\
\hline Hata & $\begin{array}{l}\text { FRG } \\
\text { FRB }\end{array}$ & $\begin{array}{l}347,2 \\
386,7\end{array}$ & $\begin{array}{l}424 \\
424 \\
\end{array}$ & $\begin{array}{l}819 \\
, 912 \\
\end{array}$ & & & \\
\hline Toplam & $\begin{array}{l}\text { FRG } \\
\text { FRB } \\
\end{array}$ & $\begin{array}{l}347,2 \\
387,8 \\
\end{array}$ & $\begin{array}{l}425 \\
425 \\
\end{array}$ & & & & \\
\hline
\end{tabular}

Reklamın güvenilirliğine yönelik olumlu veya olumsuz yönde etkilenme düzeylerinin cinsiyet değişkeninin (Erkek: $\overline{\mathrm{x}}=2,19$; Kadın: $\overline{\mathrm{x}}=2,19$ ) etkisine göre anlamlı olarak farklılaşmadığı sonucuna varılmıştır (Wilks' $\left.\Lambda=, 996, F(1,424)=, 001, p>, 05, \eta^{2}=, 000\right)$ ).

Tablo 6'da görüldüğü gibi, reklamın bilgilendiriciliğine yönelik olumlu veya olumsuz yönde etkilenme düzeylerinin de cinsiyet değişkeninin (Erkek: $\bar{x}=2,50$; Kadın: $\bar{x}=2,61$ ) etkisine göre anlamlı olarak farklılașmadığı sonucuna varılmıștır (Wilks' $\Lambda=, 996, F(1,424)=1,69, p>, 05, \eta^{2}=, 003$ ). 
Facebook reklamlarının farklı eğitim düzeyleri, gelir düzeyleri ve yaş grupları arasında, reklamın güvenilirliği ve bilgilendiriciliğine yönelik tutumda bir farklılığın olup olmadığının anlaşılması amacıyla gerçekleştirilen ANOVA testi ile ilgili bilgiler aşağıda verilmiştir.

Tablo 7: Eğitim Durumu Değişkenine Göre "Reklamın Güvenilirliğine Yönelik Tutum”a İlişkin Bağımsız Gruplar İçin Tek Faktörlü ANOVA Testi Sonuçları

\begin{tabular}{|l|c|c|c|c|c|}
\hline Varyansın kaynağı & KT & Sd & Ko & F & p \\
\hline Gruplararası & 13,8 & 3 & 4,58 & & \\
\cline { 1 - 3 } Gruplariçi & 333,4 & 422 &, 790 & \multirow{2}{*}{5,803} & \\
\cline { 1 - 3 } Toplam & 347,2 & 425 & & & \\
\hline
\end{tabular}

Tablo 7'de görüldüğü gibi, Facebook reklamlarının güvenilirliğine yönelik tutumda olumlu veya olumsuz yönde etkilenme düzeylerinin eğitim durumu değişkeninin etkisine göre anlamlı olarak

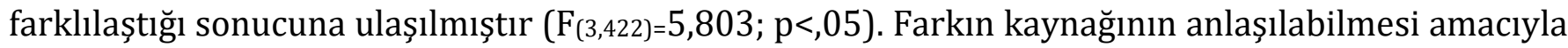
izleme testi yapılmıştır. Eşteş varyans şartı yerine getirilemediğinden Tamhane's T2 değeri yorumlanmıştır. Buna göre reklamın güvenilirliğine yönelik tutumda ilköğretim mezunları ile lise ve üniversite mezunları arasında anlamlı bir fark bulunmamıştır. Fakat üniversite mezunları $(\overline{\mathrm{x}}=2,23)$ ile lise mezunları $(\overline{\mathrm{x}}=2,06)$ arasında anlamlı bir fark bulunmuştur. Ortalamalar arasındaki farklara bakıldığında; üniversite mezunlarının lise mezunlarına göre Facebook reklamlarının güvenilirliğinden daha olumlu etkilendikleri sonucuna ulaşılmıștır. Lisansüstü mezunları ile ilköğretim, lise ve üniversite mezunları arasında anlamlı bir fark bulunmuștur. Ortalamalar arasındaki farklara bakıldığında; lisansüstü mezunlarının $(\overline{\mathrm{x}}=3,06)$ ilköğretim $(\overline{\mathrm{x}}=2,22)$, lise $(\overline{\mathrm{x}}=2,06)$ ve üniversite $(\overline{\mathrm{x}}=2,23)$ mezunlarına göre Facebook reklamlarının güvenilirliğinden daha olumlu etkilendikleri sonucuna ulaşılmıştır.

Tablo 8: Eğitim Durumu Değişkenine Göre "Reklamın Bilgilendiriciliğine Yönelik Tutum"a İlişkin Bağımsız Gruplar İçin Tek Faktörlü ANOVA Testi Sonuçları

\begin{tabular}{|l|c|c|c|c|c|}
\hline Varyansın kaynağı & KT & Sd & Ko & F & p \\
\cline { 1 - 3 } Gruplararası & 20,6 & 3 & 6,89 & & \\
Gruplariçi & 367,12 & 422 &, 870 & 7,910 & \multirow{2}{*}{, 000} \\
\cline { 1 - 4 } Toplam & 387,76 & 425 & & & \\
\hline
\end{tabular}

Tablo 8'de görüldüğü gibi, Facebook reklamlarının reklamın bilgilendiriciliğine yönelik tutumda olumlu veya olumsuz yönde etkilenme düzeylerinin eğitim durumu değişkeninin etkisine göre anlamlı olarak farklılaştığı sonucuna ulaşılmıştır $\left(F_{(3,422)=7,910 ;} p<, 05\right)$. Farkın kaynağını anlayabilmek için izleme testi yapılmıştır. Eşteş varyans şartı sağlandığından Scheffe değeri yorumlanmıştır. Buna göre reklamın bilgilendiriciliğine yönelik tutumda ilköğretim $(\overline{\mathrm{x}}=2,5)$, lise $(\overline{\mathrm{x}}=2,4)$ ve üniversite $(\overline{\mathrm{x}}=2,6)$ mezunları arasında anlamlı bir fark bulunmamıştır. Fakat lisansüstü mezunları ile ilköğretim, lise ve üniversite mezunları arasında anlamlı bir fark bulunmuştur. Ortalamalar arasındaki farklara bakıldığında; lisansüstü mezunlarının $(\bar{x}=3,6)$ ilköğretim $(\bar{x}=2,5)$, lise $(\bar{x}=2,4)$ ve üniversite $(\bar{x}=2,6)$ mezunlarına göre Facebook reklamlarının bilgilendiriciliğinden daha olumlu etkilendikleri sonucuna ulaşılmıştır. 
Tablo 9: Yaş Değișkenine Göre "Reklamın Güvenilirliğine Yönelik Tutum”a İlişkin Bağımsız Gruplar İçin Tek Faktörlü ANOVA Testi Sonuçları

\begin{tabular}{|l|c|c|c|c|c|}
\hline Varyansın kaynağı & KT & Sd & Ko & F & p \\
\cline { 1 - 4 } Gruplararası & 7,595 & 6 & 1,266 & & \multirow{2}{*}{1,562} \\
\cline { 1 - 4 } Gruplariçi & 339,581 & 419 &, 810 & \\
\hline Toplam & 347,176 & 425 & & & \\
\hline
\end{tabular}

Tablo 9'da görüldüğü gibi, Facebook reklamlarının güvenilirliğine yönelik tutumda olumlu veya olumsuz yönde etkilenme düzeylerinin yaș değișkeninin etkisine göre anlamlı olarak farklılaşmadığı

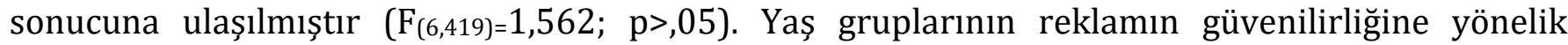
tutumda ortalama değerleri şu șekildedir: 18-23: $\overline{\mathrm{x}}=2,37 ; 24-29: \overline{\mathrm{x}}=2,07 ; 30-35: \overline{\mathrm{x}}=2,22 ; 36-41$ : $\overline{\mathrm{x}}=2,15$; 42-47: $\overline{\mathrm{x}}=2,10$; 48-53: $\overline{\mathrm{x}}=1,96$; 54 ve üzeri: $\overline{\mathrm{x}}=2,40$.

Tablo 10: Yaş Değișkenine Göre "Reklamın Bilgilendiriciliğine Yönelik Tutum”a İlişkin Bağımsız Gruplar İçin Tek Faktörlü ANOVA Testi Sonuçları

\begin{tabular}{|l|c|c|c|c|c|}
\hline Varyansın kaynağı & KT & Sd & KO & F & p \\
\cline { 1 - 3 } Gruplararası & 11,24 & 6 & 1,874 & & \\
\cline { 1 - 3 } Gruplariçi & 376,51 & 419 & 2,089 & \multirow{2}{*}{, 054} \\
\cline { 1 - 4 } Toplam & 387,76 & 425 & & & \\
\hline
\end{tabular}

Tablo 10'da görüldüğü gibi, Facebook reklamlarının bilgilendiriciliğine yönelik olumlu veya olumsuz yönde etkilenme düzeylerinin yaş değişkeninin etkisine göre anlamlı olarak farklılaşmadığı

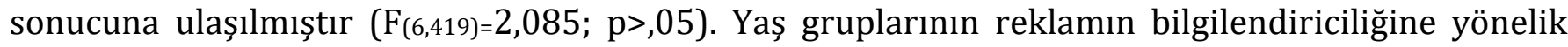
ortalama değerleri şu şekildedir: $18-23: \bar{x}=2,65 ; 24-29: \bar{x}=2,53 ; 30-35: \bar{x}=2,43 ; 36-41: \bar{x}=2,48 ; 42-47$ : $\overline{\mathrm{x}}=2,50 ; 48-53: \overline{\mathrm{x}}=2,50$; 54 ve üzeri: $\overline{\mathrm{x}}=2,87$.

Tablo 11: Gelir Değişkenine Göre "Reklamın Güvenilirliğine Yönelik Tutum”a İlişkin Bağımsız Gruplar İçin Tek Faktörlü ANOVA Testi Sonuçları

\begin{tabular}{|l|c|c|c|c|c|}
\hline Varyansın kaynağı & KT & Sd & Ko & F & p \\
\cline { 1 - 3 } Gruplararası & 3,525 & 4 &, 881 & & \multirow{2}{*}{, 366} \\
\cline { 1 - 3 } Gruplariçi & 343,65 & 421 &, 816 & 1,080 & \\
\hline
\end{tabular}

Tablo 11'de görüldüğ̈ üzere Facebook reklamlarının, reklamın güvenilirliğine yönelik tutumda olumlu veya olumsuz yönde etkilenme düzeylerinin gelir değişkeninin etkisine göre anlamlı olarak

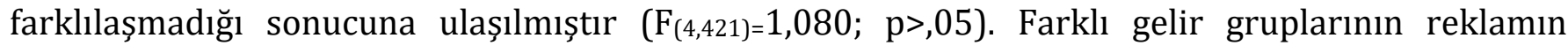
güvenilirliğine yönelik tutumda ortalama değerleri şu şekildedir: 0-2000 arası gelirliler: $\bar{x}=2,25$; 2001-3000 arası gelirliler: $\overline{\mathrm{x}}=2,08 ; 3001-4000$ arası gelirliler: $\overline{\mathrm{x}}=2,15 ; 4001-5000$ arası gelirliler: $\overline{\mathrm{x}}=2,11 ; 5000$ ve üzeri gelirliler: $\overline{\mathrm{x}}=2,40$. 
Tablo 12: Gelir Değișkenine Göre “Reklamın Bilgilendiriciliğine Yönelik Tutum”a İlişkin Bağımsız Gruplar İçin Tek Faktörlü ANOVA Testi Sonuçları

\begin{tabular}{|l|c|c|c|c|c|}
\hline Varyansın kaynağı & KT & Sd & Ko & F & p \\
\hline Gruplararası & 18,64 & 4 & 4,66 & & \\
Gruplariçi & 369,11 & 421 &, 877 & \multirow{2}{*}{5,316} & \multirow{2}{*}{000} \\
\cline { 1 - 4 } Toplam & 387,76 & 425 & & & \\
\hline
\end{tabular}

Tablo 12'de görüldüğü gibi Facebook reklamlarının, reklamın bilgilendiriciliğine yönelik tutumda olumlu veya olumsuz yönde etkilenme düzeylerinin gelir değişkeninin etkisine göre anlamlı olarak

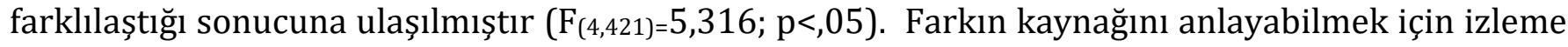
testi yapılmıştır. Eşteş varyans şartı sağlandığından Scheffe değeri yorumlanmıștır. Buna göre reklamın bilgilendirici özelliğine yönelik tutumda 0-2000 TL ( $\bar{x}=2,63), 2001-3000$ TL ( $\bar{x}=2,44), 3001$ 4000 TL $(\overline{\mathrm{x}}=2,30)$ ve 4001-5000 TL $(\overline{\mathrm{x}}=2,23)$ geliri olanlar arasında anlamlı bir fark bulunmamıştır. Fakat 5000 TL üzeri geliri olanlar ile daha düşük gelir elde edenler arasında anlamlı bir fark bulunmuştur. Ortalamalar arasındaki farklara bakıldığında; 5000 TL üzeri $(\bar{x}=3,07)$ geliri olanların diğer gelir düzeylerinde olanlara göre Facebook reklamlarının bilgilendirici özelliğinden daha olumlu etkilendikleri sonucuna ulaşılmıștır.

Hipotezlerin kabul veya ret edilme durumları tablo 13'te verilmiştir.

Tablo 13: Hipotez Testlerinin Sonuçları

\begin{tabular}{|l|c|}
\hline Hipotezler & Sonuç \\
\hline $\begin{array}{l}\text { H1. Facebook reklamlarının, reklamın bilgilendiriciliği üzerinde anlamlı } \\
\text { etkisi vardır. }\end{array}$ & Kabul Edildi. \\
\hline $\begin{array}{l}\text { H2. Facebook reklamlarının, reklamın bilgilendiriciliği üzerindeki etkisi } \\
\text { erkekler ve kadınlar arasında anlamlı olarak farklılaşmaktadır. }\end{array}$ & Reddedildi. \\
\hline $\begin{array}{l}\text { H3. Facebook reklamlarının, reklamın bilgilendiriciliği üzerindeki etkisi } \\
\text { yüksek ve düşük gelirliler arasında anlamlı olarak farklılaşmaktadır. }\end{array}$ & Kabul Edildi. \\
\hline $\begin{array}{l}\text { H4. Facebook reklamlarının, reklamın bilgilendiriciliği üzerindeki etkisi } \\
\text { farklı yaş grupları arasında anlamlı olarak farklılaşmaktadır. }\end{array}$ & Reddedildi. \\
\hline $\begin{array}{l}\text { H5. Facebook reklamlarının, reklamın bilgilendiriciliği üzerindeki etkisi } \\
\text { farklı eğitim düzeyleri arasında anlamlı olarak farklılaşmaktadır. }\end{array}$ & Kabul Edildi. \\
\hline $\begin{array}{l}\text { H6. Facebook reklamlarının, reklamın güvenilirliği üzerinde anlamlı etkisi } \\
\text { vardır. }\end{array}$ & Kabul Edildi. \\
\hline $\begin{array}{l}\text { H7. Facebook reklamlarının, reklamın güvenilirliği üzerindeki etkisi erkekler } \\
\text { ve kadınlar arasında anlamlı olarak farklılaşmaktadır. }\end{array}$ & Reddedildi. \\
\hline $\begin{array}{l}\text { H8. Facebook reklamlarının, reklamın güvenilirliği üzerindeki etkisi yüksek } \\
\text { ve düşük gelirliler arasında anlamlı olarak farklılaşmaktadır. }\end{array}$ & Reddedildi. \\
\hline $\begin{array}{l}\text { H9. Facebook reklamlarının, reklamın güvenilirliği üzerindeki etkisi farklı } \\
\text { yaş grupları arasında anlamlı olarak farklılaşmaktadır. }\end{array}$ & Reddedildi. \\
\hline $\begin{array}{l}\text { H10. Facebook reklamlarının, reklamın güvenilirliği üzerindeki etkisi farklı } \\
\text { eğitim düzeyleri arasında anlamlı olarak farklılaşmaktadır. }\end{array}$ & Kabul Edildi. \\
\hline
\end{tabular}




\section{SONUÇ, TARTIŞMA VE ÖNERİLER}

Çalışmadan elde edilen sonuçlara göre tüketiciler Facebook reklamlarını bilgilendirici ve güvenilir görmemektedirler. Bannister ve arkadaşları (2013: 16)'nın çalışmasında, Facebook reklamlarına yönelik duyguların ya olumsuz olduğu ya da katılımcıların bu reklamlara karşı kayıtsız kaldığı sonucuna varılmıştır. Facebook reklamlarının alakasız olduğu ve bilgilendirici olmadığı araştırmanın başka sonuçları arasındadır. Bir mecra olarak Facebook'a yönelik tutumlar olumlu olsa da bu olumlu tutum reklama yönelik olarak olumlu yönde gerçekleşmediği belirtilmiştir.

Facebook reklamlarına karşı olumsuz tutumların olmasının nedeni, Facebook'a karşı olumlu tutumların olduğu ve reklamların tüketiciler tarafından Facebook ile olan diğer etkileşimleri olumsuz yönde etkilediği, bu durumun tüketicileri rahatsız ettiği ve bundan dolayı tüketicilerin bu reklamlara karşı olumsuz tutumlar içinde olduğu düşünülmektedir.

Çalışmadan elde edilen sonuçlar, daha önce yapılan çalışmaların (Bannister vd., 2013: 16; Barreto, 2013: 135) sonuçları ile benzer şekilde Facebook reklamlarının firmalar açısından istenilen sonuçları doğurmadığını göstermiştir.

Elde edilen diğer sonuçlara göre, yaş ve cinsiyet değişkenleri göz önüne alındığında farklı yaş grupları arasında ve erkekler ile kadınlar arasında Facebook reklamlarının bilgilendiriciliğine ve güvenilirliğine yönelik tutumlarda herhangi bir farklılığa rastlanmamıștır. Literatürde de (Barreto, 2013: 135) benzer şekilde cinsiyet değişkeninin herhangi bir farklılığa neden olmadığı görülmüştür.

Eğitim durumu değişkeni ile ilgili sonuçlarda, lisansüstü mezunlarının diğer eğitim gruplarında olanlara göre Facebook reklamlarının daha güvenilir ve bilgilendirici olduğunu düşündükleri görülmüştür. Eğitim düzeyinin artması ile birlikte Facebook reklamlarına yönelik daha olumlu tutumların olması, reklamların daha iyi anlaşılması ile beraber olumlu tutumların da oluştuğu şeklinde yorumlanabilir.

Gelir düzeyi değişkeni ile ilgili sonuçlara bakıldığında, geliri 5000 TL üzerinde olanların daha düşük geliri olanlara göre Facebook reklamlarının daha bilgilendirici olduğunu düşündükleri görülmüştür. Geliri yüksek olanların, düşük gelirlilere göre bir ürünü satın alma olasılığının daha yüksek olması ve bundan dolayı Facebook'ta verilen reklamlara daha fazla dikkat ettiğinden reklamdan daha çok bilgi elde ettiği, bunun da Facebook reklamlarını daha bilgilendirici gördüklerine neden olduğu düşünülmektedir.

Facebook'ta verilen reklamların bilgilendirici olmadığı sonucu, Barreto (2013: 134-135) ve Bannister'in (2013: 16) sonuçları ile paralellik göstermektedir. Ayrıca Facebook'ta verilen reklamların bilgilendirici olup olmamasına yönelik tutumda, kadınlar ve erkekler arasında herhangi bir farklılığa rastlanılmaması sonucu Barreto'nun (2013: 134-135) sonucu ile benzerlik göstermektedir. Facebook'ta verilen reklamların, reklamın bilgilendiriciliği üzerinde meydana getirdiği etki ile ilgili çok az sayıda çalışma (Bannister vd., 2013; Barreto, 2013) olmasından ve bu reklamların, reklamın güvenilirliğine olan etkisini araştıran bir çalışmaya rastlanılmamasından dolayı çalışmamızda elde edilen sonuçların başka çalışma sonuçları ile karşılaştırabilme imkânımız sadece iki çalışma (Bannister vd., 2013; Barreto, 2013) ile sınırlı olmuştur.

Çalışmadan elde edilen sonuçlara göre aşağıda bazı öneriler verilmiştir:

Sonuçlar Facebook reklamlarının firmalar açısından istenilen sonuçları doğurmadığını göstermiștir. $\mathrm{Bu}$ sonuçlara bakıldığında Facebook gibi devasa bir platformdan reklamın bilgilendiriciliği ve güvenilirliği bağlamında istenilen sonuçlara neden ulaşılamadığının anlaşılması firmalar açısından oldukça önemli olup, firmalar tarafından buna yönelik gereken araştırmaların yapılması ya da profesyonel araştırma firmalarına yaptırılması önerilmektedir. 
Reklamların bilgilendiriciliğinin reklam etkinliğinin artmasına katkı sunabilmesi (Goodrich vd., 2015: 39), reklama yönelik olumlu tutumlara neden olması (Janssens ve De Pelsmacker, 2005: 387; Edwards vd., 2002: 92) ve markaya yönelik olumlu tutumlara neden olması (Janssens ve De Pelsmacker, 2005: 387) ayrıca reklam güvenilirliğinin ikna etmenin öncülü, reklamda verilen bilginin kabul edilmesi ve tüketici satıcı arasındaki ilişkilerin yapı tașı olmasından (Soh vd., 2007: 455-456) dolayı firmalar tarafından bu konuda gereken araștırmaların yapılmasının firmalara büyük faydalar sağlayabileceği değerlendirilmektedir. Ayrıca bu araştırmalar yapılırken reklama yönelik tutumların farklı demografik özellikler göz önüne alınarak yapılmasının oldukça önemli olduğu (Shavit vd., 1998: 7) düşünülmektedir.

Elde edilen bulgulara göre, gelir düzeyi yüksek olanların düşük gelirli olanlara göre Facebook reklamlarını daha bilgilendirici görmesi nedeniyle, firmaların etkin bir pazar bölümlendirme ile daha yüksek gelirlilere Facebook reklamları ile ulaşmalarının daha verimli pazarlama iletişimi çabalarına neden olacağı düşünülmektedir. Zira firmaların reklam çabalarında hedef kitleye uygun, alakalı ve daha çok kişiselleştirilmiş reklam stratejileriyle pazarlama iletişimi amaçlarına ulaşacakları değerlendirilmektedir.

Araştırma, Erciş ilçesinde gerçekleştirilmiş olup farklı sosyal, kültürel ve ekonomik özelliklere sahip yerlerde benzer çalışmalar yapılabilir. Çalıșmada, yalnızca Facebook reklamlarının etkileri araştırılmış olup diğer sosyal medya platformlarındaki reklamların, reklamın bilgilendiriciliği ve güvenilirliğine yönelik tutumu araştıran çalışmalar yapılabilir.

Araştırmada cinsiyet, yaş, gelir ve eğitim durumu gibi değişkenlerde farklılıkların olup olmadığı araştırılmış olup medeni durum gibi çalışmada yer almayan değişkenlerin ele alınıp Facebook reklamlarının, reklamın bilgilendiriciliği ve güvenilirliğine yönelik tutumu araştıran çalışmalar yapılabilir. Farklı bir ülkede tamamen farklı bir kültürde olan insanlar ile yapılacak benzer bir çalışma ile Türkiye'de gerçekleştirilecek bir çalışma karşılaştırılarak, ortaya çıkacak farklılık veya benzerliklerin sebeplerini araștıran çalışmalar yapılabilir.

Çalışma sonuçlarına göre Facebook'ta verilen reklamlara karşı olumsuz tutumların oluşmasının nedeni olarak bu reklamların, beğenilen sosyal platform ile tüketicilerin etkileşimlerini olumsuz yönde etkilemiş olmasından kaynaklı olduğu düşünülmektedir. Fakat Facebook'ta verilen reklamlara karşı oluşan olumsuz tutumların nedenlerinin daha ayrıntılı araştırıldığı akademik çalışmaların yapılması, bu reklamlara karşı olumsuz tutumların tüm yönleriyle anlaşılabilmesine olanak tanıyabilir. Böyle bir çalışmanın yapılmasının literatüre oldukça önemli katkı sağlayacağı düşünülmektedir. 


\section{KAYNAKÇA}

Akar, E. ve Topçu, B. (2011). An Examination of the Factors Influencing Consumers' Attitudes Toward Social Media Marketing. Journal of Internet Commerce, 10(1), 35-67.

Akbulut, Y. (2010). Sosyal Bilimlerde SPSS Uygulamaları. İstanbul: İdeal Kültür Yayıncılık.

Alpar, R. (2011). Uygulamalı Çok Değişkenli İstatistiksel Yöntemler. Ankara: Detay Yayıncılık.

Aslan, İ. ve Yaşar, M. E. (2020). Measuring Social Media Addiction Among University Students. International Journal of Contemporary Economics and Administrative Sciences, 10(2), 468492.

Aydın, İ. (2020). Geleneksel ve Yeni Mecralar. A. Mermer Üzümlü (Ed.), Tüm Yönleriyle Bütünleşik Pazarlama İletişimi içinde (107-124 ss.), Ankara: Nobel Akademik Yayıncılık Eğitim Danışmanlık Tic. Ltd. Şti.

Bannister, A., Kiefer, J. ve Nellums, J. (2013). College Students' Perceptions of and Behaviours Regarding Facebook Advertising: An Exploratory Study. The Catalyst, 3 (1), 1-20.

Barreto, A. M. (2013). Do Users Look at Banner Ads on Facebook?. Journal of Research in Interactive Marketing, 7(2), 119-139.

Chandra, B., Goswami, S. ve Chouhan, V. (2012). Investigating Attitude Towards Online Advertising on Social Media - an Empirical Study. Management Insight: The Journal of Incisive Analyzers, 8 (1), 1-14.

Chi, H. H. (2011). Interactive Digital Advertising vs Virtual Brand Community: Exploratory Study of User Motivation and Social Media Marketing Responses in Taiwan. Journal of Interactive Advertising, 12(1), 44-61.

Constantinides, E. ve Fountain, S. J. (2008). Web 2.0: Conceptual Foundations and Marketing Issues. Journal of Direct Data and Digital Marketing Practice, 9(3), 231-244.

Dehghani, M. ve Tumer, M. (2015). A Research on Effectiveness of Facebook Advertising on Enhancing Purchase Intention of Consumers. Computers in Human Behavior, 49, 597-600.

Duffett, R. G. (2017). Influence of Facebook Commercial Communications on Generation z's Attitudes in South Africa. The Electronic Journal of Information Systems in Developing Countries, 81(1), $1-22$.

Dülek, B. ve Aydın, İ. (2020). Effect of Social Media Marketing on E-Wom, Brand Loyalty, and Purchase Intent. Bingöl Üniversitesi Sosyal Bilimler Enstitüsü Dergisi, (20), 271-288.

Evans, D. ve Mc Kee, J. (2010). Social Media Marketing the Next Generation of Business Engagement. Wiley Publishing, Ink.

Edwards, S. M., Li, H. ve Lee, J. H. (2002). Forced Exposure and Psychological Reactance: Antecedents and Consequences of the Perceived Intrusiveness of Pop-Up Ads. Journal of Advertising, 31(3), 83-95.

Goodrich, K., Schiller, S. Z. ve Galletta, D. (2015). Consumer Reactions to Intrusiveness of Online-Video Advertisements: Do Length, Informativeness, and Humor Help (Or Hinder) Marketing Outcomes?. Journal of Advertising Research, 55(1), 37-50.

Gümüş, N., Zengin, H. ve Geçti, F. (2013). Sosyal Medya Aracı Olarak Facebook Uygulamalarının Marka Denkliği Üzerindeki Etkisi: Bir Gsm Operatörünün Facebook Sayfası Üzerinde Araştırma. Sakarya İktisat Dergisi, 2 (2), 87-117. 
Hajli, N. M. (2014). A Study of the Impact of Social Media on Consumers. International Journal of Market Research, 56 (3), 387-404.

Hazar, M. (2011). Sosyal Medya Bağımlılı̆̆ı Bir Alan Çalışması. İletişim Kuram ve Araştırma Dergisi. (32), 151-175.

Janssens, W. ve Pelsmacker, P. D. (2005). Emotional or Informative? Creative or Boring? The Effectiveness of Different Types of Radio Commercial. International Journal of Advertising, 24(3), 373-394.

Kazançoğlu, P., Üstündağlı, E. ve Baybars, M. (2012). Tüketicilerin Sosyal Ağ Sitelerindeki Reklamlara Yönelik Tutumlarının Satın Alma Davranışları Üzerine Etkisi: Facebook Örneği. International Journal of Economic and Administrative Studies, 4(8), 159-182.

Kim, A. J. ve Ko, E. (2010). Impacts of Luxury Fashion Brand's Social Media Marketing on Customer Relationship and Purchase Intention. Journal of Global Fashion Marketing, 1(3): 164-171.

Kotler, P. ve Armstrong, G. (2018). Principles of Marketing. Harlow: Pearson Education Limited.

Krejcie, R. V. ve Morgan, D. W. (1970). Determining Sample Size for Research Activities. Educational and Psychological Measurement, (30), 607-610.

Lewis, B. K. (2010). Social Media and Strategic Communication: Attitudes and Perceptions Among College Students. Public Relations Journal, 4(3).

Mir, I. A. (2012). Consumer Attitudinal Insights About Social Media Advertising: A South Asian Perspective. The Romanian Economic Journal, 15(45), 265-288.

Nufusu.com (2020). Erciş Nüfusu - Van. Erişim Adresi https://www.nufusu.com/ilce/ercis_vannufusu\#: :text=Erci\%C5\%9F\%20n\%C3\%BCfusu\%202019\%20y\%C4\%B11\%C4\%B1na\%20g \%C3\%B6re,\%2C\%20\%48\%2C39\%20kad\%C4\%B1nd\%C4\%B1r

Özdalili, S., Ertugan, A. ve Medeni, T. D. (2018). Kullanıcıların Facebook’a Olan Duygusal Bağlılıkları ve Facebook'taki Reklamlara Karşı Gösterdikleri Tavırlar. Ajıt-E: Bilişim Teknolojileri Online Dergisi, 9(33), 77-90.

Sharma, S. (1996). Applied Multivariate Techniques. New York: John Wiley \& Sons Inc.

Shavitt, S., Lowrey, P. ve Haefner, J. (1998). Public Attitudes Toward Advertising: More Favorable Than You Might Think. Journal of Advertising Research, 38(4), 7-22.

Sheth, J. N. (2018). How Social Media Will Impact Marketing Media. G. Heggde ve G. Shainesh (Ed.), Social media marketing emerging concepts and applications içinde (3-18 ss.), Singapore: Springer.

Soh, H., Reid, L. N. ve King, K. W. (2007). Trust in Different Advertising Media. Journalism \& Mass Communication Quarterly, 84(3), 455-476.

Statista (2020). Most Popular Social Networks Worldwide as of October 2020, ranked by number of active users. Erişim Adresi https://www.statista.com/statistics/272014/global-socialnetworks-ranked-by-number-of-users/

Stevens, J. P. (2009). Applied Multivariate Statistics for the Social science. New York: Routledge, Taylor and Francis Group.

Tabachnick B. G. ve Fidell, L. S. (2015). Çok Değişkenli İstatistiklerin Kullanımı. (Çev. M. Baloğlu). Ankara: Nobel Akademik Yayıncılık Eğitim Danıșmanlık Tic. Ltd. Şti. (Orijinal yayın tarihi, 2013)

Torlak, Ö. ve Ufuk, A. Y. (2014). Facebook'ta Bulunma Amacı ve Facebook Reklamlarına Duyulan İlgi Arasındaki İlişki. Anadolu Üniversitesi Sosyal Bilimler Dergisi, 14(4), 83-94. 
S.S. Kendir, İ. Aydın, İ.A. Karataş, B. Dülek

Izmir Íktisat Dergisi / İzmir Journal of Economics

Yll/Year: 2022 Cilt/Vol:37 Sayı/No:1 Doi: 10.24988/ije.886419

(C) Submitted for possible open access publication under the terms and conditions of the Creative Commons Attribution (CC BY NC) license.

(https://creativecommons.org/licenses/by-nc/4.0/). 


\section{EXTENDED ABSTRACT}

\section{Investigation of the Effects of Advertising on Facebook on Reliability and Informativeness of Advertising}

\section{Introduction}

The widespread use of tools that provide access to the Internet and their use almost everywhere, the emergence of new digital environments, and the more effective use of the Internet have caused communication tools such as radio, television, and newspaper to be seen as traditional media. Television, which was previously mentioned in the new media, is now included in the traditional media (Aydın, 2020: 110). A few decades ago, television was the most exciting technological development and transformed society in an unprecedented way. Today, a similar transformation and the rise of social media are seen on the internet. In the changing world, technology affects society with its rapid change wherever it exists (Sheth, 2018: 3). Consumers can communicate with companies and people almost everywhere at any time of the day, control information in various ways, and create content via the internet (Aydın, 2020: 116).

The effectiveness of an advertisement may depend on its informativeness (Goodrich et al., 2015: 39). In addition, advertisements containing useful information are better received (Edwards et al., 2002: 92). Informative advertisements cause positive attitudes towards the brand as well as positive attitudes towards the advertisement (Janssens and De Pelsmacker, 2005: 387). Informative applications on Facebook pages have an impact on brand value dimensions (brand awareness and associations, perceived quality, and brand loyalty) (Gümüş et al., 2013: 87).

One of the main purposes of advertising is to inform (Kotler and Armstrong, 2018: 453). To fulfill this purpose, it is very important for consumers to trust advertisements as a source of information. Because trust; is the premise of persuasion, acceptance of information, and the basic building block of consumer-seller relations (Soh et al., 2007: 455-456).

In the literature review, no study was found that investigated the effect of advertisements on Facebook on the reliability of the advertisement. On the other hand, there has been no study that investigated the variables of age, income, and educational status on the effect of advertisements on Facebook on the informativeness of the advertisement. It is expected that these unique aspects of the study will contribute to the literature. It is thought that it will be important for the business world to understand how consumers are affected by advertisements on a platform such as Facebook, which gives the business world the opportunity to reach large audiences.

\section{Data Set and Method}

The population of this study consists of 175,108 people living in the Erciş district of Van in October and November 2019 (Nufusu.com, 2020). The sample of the research is; In the first stage, it consisted of 507 people selected from the universe by simple random sampling method. For the validity of the sample's degree of representation of the universe, the formula used by Krejcie and Morgan (1970: 608 ) to determine the required sample size was used. In the calculation, it was determined that a sample of 384 people in a population of 175.108 people would be sufficient for a $95 \%$ confidence level.

Suitable according to the properties of the variables; one-sample t-test, one-way MANOVA, and onefactor ANOVA analyzes were used.

\section{Empirical Findings}

It was concluded Facebook ads negatively affected the participants in their attitudes towards the reliability and informativeness of the ad. Besides, it was concluded the levels of positive or negative 
effects on the reliability and informativeness of the advertisement did not differ significantly according to the effect of the gender variable.

It has been concluded the level of positive or negative influence on the reliability and informativeness of Facebook ads differs significantly according to the effect of the educational status variable. It has been concluded graduates of masters and doctoral are more positively affected by the reliability and informativeness of Facebook ads than primary, high school, and university graduates. Besides, it was concluded that the level of positive or negative effects on the attitude towards the reliability and informativeness of Facebook ads did not differ significantly according to the effect of the age variable. Also, it has been concluded the positive or negative effects of Facebook ads on the attitude towards the informativeness of the ad differ significantly according to the effect of the income variable. It has been concluded that those with an income of more than $5000 \mathrm{TL}$ are more positively affected by the informative feature of Facebook ads than those with other income levels.

\section{Discussion and Conclusion}

The results obtained from the study showed that similar to the results of previous studies (Bannister et al., 2013: 16; Barreto, 2013: 135), Facebook ads did not produce the desired results for companies. It is thought the reason for the negative attitudes towards Facebook ads is that there are positive attitudes towards Facebook and the ads negatively affect other interactions with Facebook by consumers, this situation disturbs consumers and therefore consumers have negative attitudes towards these ads.

According to other results, there was no difference in attitudes towards the informativeness and reliability of Facebook ads between different age groups and between men and women, considering age and gender variables. Similarly, in the literature (Barreto, 2013: 135), it was seen that the gender variable did not cause any difference.

In the results related to the educational status variable, it was seen that postgraduate graduates thought that Facebook ads were more reliable and informative than those in other education groups. The fact that there are more positive attitudes towards Facebook ads with the increase in education level can be interpreted as positive attitudes being formed with a better understanding of the ads.

When the results related to the income level variable are examined, it is seen that those with an income of more than 5000 TL think that Facebook ads are more informative than those with a lower income. It is thought that those with high incomes are more likely to buy a product than those with low incomes, and therefore they get more information from the advertisement because they pay more attention to the advertisements on Facebook, which causes them to see Facebook advertisements as more informative. 